OPEN ACCESS

Edited by:

Eduardo Jacob-Lopes,

Federal University of Santa Maria,

Brazil

Reviewed by:

Ola M. Gomaa

Egyptian Atomic Energy Authority,

Egypt

Mohamad Nasir Mohamad Ibrahim,

Universiti Sains Malaysia, Malaysia

John Greenman,

University of the West of England,

United Kingdom

*Correspondence:

Hamid Mukhtar

hamidwaseer@yahoo.com

Specialty section:

This article was submitted to

Bioprocess Engineering,

a section of the journal

Frontiers in Bioengineering and

Biotechnology

Received: 26 July 2021 Accepted: 08 October 2021

Published: 12 November 2021

Citation:

Miran F, Mumtaz MW, Mukhtar H and Akram S (2021) Iron Oxide-Modified

Carbon Electrode and SulfateReducing Bacteria for Simultaneous Enhanced Electricity Generation and

Tannery Wastewater Treatment. Front. Bioeng. Biotechnol. 9:747434.

doi: 10.3389/fbioe.2021.747434

\section{Iron Oxide-Modified Carbon Electrode and Sulfate-Reducing Bacteria for Simultaneous Enhanced Electricity Generation and Tannery Wastewater Treatment}

\author{
Faiz Miran ${ }^{1}$, Muhammad Waseem Mumtaz ${ }^{1}$, Hamid Mukhtar ${ }^{2 *}$ and Sadia Akram ${ }^{1}$ \\ ${ }^{1}$ Department of Chemistry, University of Gujrat, Gujrat, Pakistan, ${ }^{2}$ Institute of Industrial Biotechnology, Government College \\ University, Lahore, Pakistan
}

The microbial fuel cell (MFC) is emerging as a potential technology for extracting energy from wastes/wastewater while they are treated. The major hindrance in MFC commercialization is lower power generation due to the sluggish transfer of electrons from the biocatalyst (bacteria) to the anode surface and inefficient microbial consortia for treating real complex wastewater. To overcome these concerns, a traditional carbon felt (CF) electrode modification was carried out by iron oxide $\left(\mathrm{Fe}_{3} \mathrm{O}_{4}\right)$ nanoparticles via facile dip-and-dry methods, and mixed sulfate-reducing bacteria (SRBs) were utilized as efficient microbial consortia. In the modified CF electrode with SRBs, a considerable improvement in the bioelectrochemical operation was observed, where the power density (309 \pm $\left.13 \mathrm{~mW} / \mathrm{m}^{2}\right)$ was 1.86 times higher than bare CF with SRBs $\left(166 \pm 11 \mathrm{~mW} / \mathrm{m}^{2}\right)$, suggesting better bioelectrochemical performance of an SRB-enriched $\mathrm{Fe}_{3} \mathrm{O}_{4} @ \mathrm{CF}$ anode in the MFC. This superior activity can be assigned to the lower charge transfer resistance, higher conductance, and increased number of catalytic sites of the $\mathrm{Fe}_{3} \mathrm{O}_{4} @ \mathrm{CF}$ electrode. The SRB-enriched $\mathrm{Fe}_{3} \mathrm{O}_{4} @ \mathrm{CF}$ anode also assists in enhancing MFC performance in terms of COD removal $(>75 \%)$, indicating efficient biodegradability of tannery wastewater and a higher electron transfer rate from SRBs to the conductive anode. These findings demonstrate that a combination of the favorable properties of nanocomposites such as $\mathrm{Fe}_{3} \mathrm{O}_{4} @ \mathrm{CF}$ anodes and efficient microbes for treating complex wastes can encourage new directions for renewable energy-related applications.

Keywords: microbial fuel cell, tannery wastewater treatment, sulfate-reducing bacteria, iron nanoparticles (Fe NPs), electricity generation

\section{INTRODUCTION}

The current challenges faced by the world regarding sustainable energy production and water pollution require the development of novel technologies that can aim to amicably solve these problems (Luderer et al., 2019; Sun et al., 2020). The microbial fuel cell (MFC) is developing as a potential biotechnology which can help in tackling these challenges as electricity production and wastewater treatment are concurrently accomplished by bacteria as biocatalysts (Yaqoob et al., 2020; Yaqoob et al., 2021). Importantly, such a technology aiming at energy self-sufficiency in wastewater 
treatment systems is highly vital for the developing countries which often lack the fiscal capitals required for the proper wastewater treatment infrastructures (Gu et al., 2017; Maktabifard et al., 2018). Given that lower MFC efficiencies are a hurdle in its commercialization, and the anode electrode and microbial communities play a fundamental role in electricity generation and pollutant removal (Choudhury et al., 2017), research on these aspects can help in enhancing the performance of MFCs to commercially acceptable levels.

Tanneries are water-intensive industries which use as much as $70 \mathrm{~L}$ of water in processing $1 \mathrm{~kg}$ of raw hide/skin to manufacture leather (Thanikaivelan et al., 2004), where downstream effluents become toxic with chemicals and organic impurities (Rafique et al., 2010). Tanneries also produce sulfate-rich wastewater owing to the use of $\mathrm{H}_{2} \mathrm{SO}_{4}$ and the addition of sulfides in the unhairing process that oxidizes to sulfate before entering into the sewer (Galiana-Aleixandre et al., 2011). Since polluted water with a large number of noxious contaminants discharged from these tanneries penetrates the water tables, it causes severe diseases of the respiratory tract and digestive system to humans (Bhalli and Khan, 2006). Therefore, treating tannery waste before discharging into the water bodies is of great importance. The biological treatment of tannery wastes in comparison to physical, chemical, and advanced oxidation approaches is an inexpensive and green approach with lower sludge generation (Durai and Rajasimman, 2011). MFCs can aid in further accelerating the biodegradation of tannery pollutants, as the MFC has an infinite terminal electron acceptor (anode) in comparison to exhaustible electron acceptors like $\mathrm{O}_{2}$ and $\mathrm{NO}_{3}{ }^{-}$, with electricity production as an added benefit (Chen et al., 2016). To this end, local tannery wastewater from Sialkot (an industrial city), Pakistan, was evaluated for treatment in the MFC system. Currently, more than 270 tanneries are operating in about ten clusters in the vicinity of Sialkot and accommodate the increasing manufacturing needs. Sulfate was first reduced to sulfite and then reoxidized to sulfate by forming thiosulfate as an important intermediate or by direct sulfite oxidation.

The microbial consortia of the MFC can considerably affect the electricity production capacity and treatment efficiency (Choudhury et al., 2017; Hassan et al., 2018). Incidentally, the sulfate-reducing bacteria (SRBs) have been found to be a very potent group for efficient generation of current as compared to the electroactive environmental bacteria already known (i.e., Geobacter and Shewanella) (Kang et al., 2014). Zhang et al. (2009) have shown the probability of manipulating the SRBs for transforming sulfates to sulfides, and then electrons can be obtained indirectly via abiotic oxidation of microbially generated sulfide at the anode. In another study, Lee et al. (2012) have proven that the SRB group can transform sulfates to sulfides, and then the MFC anodic biofilm can carry out the oxidation of sulfide to elemental sulfur along with electricity generation. Redox voltage of the half-cell also plays a significant role in such systems. For instance, partial sulfur reuse in electrode potential control MFCs has also been shown to participate in current generation. At lower poised potentials, thiosulfate was detected as the reduced product of sulfate and was effectively oxidized, particularly under $-0.1 \mathrm{~V}$ vs SHE. The anode at lower poised potentials, for example, $-0.2 \mathrm{~V}$, largely accumulates genes for thiosulfate and sulfite reduction. The oxidation of thiosulfate to tetrathionate and sulfide to sulfur or polysulfide has also been confirmed at lower poised potentials of -0.1 and $-0.2 \mathrm{~V}$ vs SHE (Zhang et al., 2020a). It has also been revealed that efficient removal of sulfate and organic carbon by the MFC is possible with the help of the anodic biofilm of SRBs and sulfide-oxidizing bacteria (Lee et al., 2014). These previous investigations revealed only the potential of SRBs for simple carbon source biodegradation, sulfate reduction, and electricity production; however, the advanced capabilities of SRBs in MFCs are still unexplored. SRB comprise a diverse group of essential anaerobes, which have the capacity of dissimilating sulfate to sulfide and to oxidize many types of substrates (Willis et al., 1997). Based on the potential of SRBs, huge importance is being given for the implementation of SRBs for the complex industrial waste remediation. For example, SRBs have been utilized for the biotreatment of many complex contaminants such as phenanthrene, cyclohexane, naphthalene, metals, and 2,4,6trinitrotoluene (Hussain et al., 2016). Furthermore, SRB groups can also attain extraordinary removal of complex organic waste and sulfate under anaerobic environments (Rasool et al., 2013). Consequently, SRBs would be a potent microbial culture in MFCs, which might enhance the overall waste product treatment capability and energy generation from tannery wastewater.

Electroconductive nanoparticles have been shown to transfer electrons across the outer membrane (OM) of Gram-negative microbes. Metallic nanoparticles synthetically produced on the surface of the cell-aided electron transport from the inside of the cell across the OM to the cell outer surface, thus functioning as electron conductors across the OM (Malvankar et al., 2015). Likewise, it has been shown that the biosynthesized iron-based nanocluster attachment with the cell surface provides a pathway for electron transfer across the $\mathrm{OM}$ to extracellular electrodes (Nakamura et al., 2010; Zhou et al., 2014). Furthermore, the model of electron transport to electrodes by the SRBs has been suggested (Murugan et al., 2018). Thus, the possibility of ironbased nanocluster-mediated electron transport to the anode via SRB has offered new ways to enhance the efficiency of SRB MFCs. Since this has not been explored before in MFCs for real wastewater systems, we are combining the two strategies to improve MFC efficiency.

The aim of this study was to evaluate the MFC performance utilizing a carbon felt electrode fabricated with $\mathrm{Fe}_{3} \mathrm{O}_{4}$ nanoparticles for the treatment of tannery wastewater by applying mixed SRB in an anaerobic chamber of the MFC, with simultaneous bioelectricity generation. Many characterization techniques such as FTIR, XRD, and TEM were employed to confirm the successful synthesis of $\mathrm{Fe}_{3} \mathrm{O}_{4}$ nanoparticles. The bioelectrochemical performance of the MFC was estimated by the generation of voltage, power, and current density. Furthermore, wastewater treatment efficacy was assessed by the removal of chemical oxygen demand (COD) and sulfate reduction. Although continuous flow systems have many advantages for studying fuel cells (Habermann and Pommer, 1991), here we used the batch MFC system for making it less 
complicated and easier to establish and manage for our first such study where we are treating complex wastewater using an anodemodified electrode and mixed electroactive SRBs.

\section{MATERIALS AND METHODS}

\section{Preparation of $\mathrm{Fe}_{3} \mathrm{O}_{4}$ Nanoparticles}

$\mathrm{Fe}_{3} \mathrm{O}_{4}$ nanoparticle synthesis was carried out by adopting a solvothermal method, as previously reported along with some moderations in the procedure (Zhang et al., 2020b). $1 \mathrm{~g}$ of $\mathrm{FeCl}_{3} \cdot 6 \mathrm{H}_{2} \mathrm{O}$ was added to $20 \mathrm{ml}$ of ethylene glycol, and a clear solution was obtained upon stirring. After that in the acquired solution, $10 \mathrm{ml}$ of ethylene diamine and $3 \mathrm{~g}$ of sodium acetate were added and stirred at ambient temperature for $30 \mathrm{~min}$. The mixture was then poured into a Teflon-lined autoclave having $50 \mathrm{ml}$ capacity and was heated in an oven at $180^{\circ} \mathrm{C}$ for $8 \mathrm{~h}$. The resultant blackcolored product was washed repeatedly with distilled water/ethanol, followed by desiccation to gain a dry product. This drying led to the formation of a magnetic iron powder.

\section{Characterization of $\mathrm{Fe}_{3} \mathrm{O}_{4}$ Nanoparticles}

The formation of $\mathrm{Fe}_{3} \mathrm{O}_{4}$ nanoparticles, their purity, size, and morphology were affirmed by the help of various analytical techniques. Dimensions, crystal phase, and size of the nanoparticles were evaluated by X-ray diffraction, using an X'pertpro (PANalyatical) XRD model. FT-IR spectroscopy of the nanoparticles in the scanning range $4,000-600 \mathrm{~cm}^{-1}$, using the Cary 630 Agilent FT-IR spectrometer, was performed to check the purity of the nanoparticles. Morphological characterization was carried out by transmission electron microscopy (TEM) (Tecnai $\mathrm{G}^{2}$ F20 U-TWIN), with an accelerating voltage of $200 \mathrm{kV}$. The size and morphology of the nanoparticles were also assessed by SEM microscopy (Model JSM5910, JEOL, Japan), with $30 \mathrm{kV}$ energy, a maximum magnification of $300,000 \mathrm{x}$, and $2.3 \mathrm{~nm}$ resolving power, while the purity and elemental ratio of iron and oxygen in nanoparticles were estimated by using EDX (JSM5910) (INCA200/Oxford instruments, United Kingdom).

\section{Preparation of $\mathrm{Fe}_{3} \mathrm{O}_{4} @ \mathrm{CF}$ Electrode}

The coating of nanoparticles on the surface of electrodes was effectively achieved by dipping CF anodes in a Teflon-based autoclave in the solution of $\mathrm{Fe}_{3} \mathrm{O}_{4}$ sustained at $180^{\circ} \mathrm{C}$ for $20 \mathrm{~h}$. The autoclave was cooled down to room temperature $\left(25^{\circ} \mathrm{C}\right)$, and deionized water was used to wash the $\mathrm{Fe}_{3} \mathrm{O}_{4}$-coated anodes. The surface-modified electrodes were then placed in the vacuum oven at $60^{\circ} \mathrm{C}$ for $24 \mathrm{~h}$ for the purpose of drying. The amount of $\mathrm{Fe}_{3} \mathrm{O}_{4}$ deposited on the surface of $\mathrm{Fe}_{3} \mathrm{O}_{4} @ \mathrm{CF}$ was measured as a count of difference in the weight of electrodes before and after the process of coating that was estimated to be $8.3 \mathrm{mg}$, suggesting that $\mathrm{CF}$ exhibited high potential for $\mathrm{Fe}_{3} \mathrm{O}_{4}$ coating by this methodology.

\section{Tannery Wastewater and Microbial Culture}

Tannery wastewater was obtained from local tanneries in the tannery zone, Sialkot, Pakistan, in 1-L glass bottles, which was mixed in a large 5 - $\mathrm{L}$ beaker to get the representative sample. The
TABLE 1 | Physicochemical composition of tannery wastewater.

\begin{tabular}{lc}
\hline Parameter & Value \\
\hline TDS $(\mathrm{g} / \mathrm{L})$ & 4.450 \\
$\mathrm{TSS}(\mathrm{g} / \mathrm{L})$ & 0.3345 \\
$\mathrm{COD}(\mathrm{g} / \mathrm{L})$ & 3.455 \\
$\mathrm{BOD}(\mathrm{g} / \mathrm{L})$ & 0.224 \\
$\mathrm{Cr}(\mathrm{mg} / \mathrm{L})$ & 6.44 \\
$\mathrm{Ni}(\mathrm{mg} / \mathrm{L})$ & 0.22 \\
$\mathrm{Mn}(\mathrm{mg} / \mathrm{L})$ & 0.17 \\
$\mathrm{Cd}(\mathrm{mg} / \mathrm{L})$ & 0.74 \\
$\mathrm{EC} \mathrm{dS} / \mathrm{m}$ & 17.92
\end{tabular}

samples were stored at $4 \mathrm{C}$ before the physicochemical characterization and used in the MFC as the anolyte. Physicochemical compositions of the tannery wastewater are provided in Table 1. The initial microbial inoculum was also collected from a tannery wastewater treatment plant in the tannery zone, Sialkot, Pakistan. The collected sludge was pretreated by removing the foreign particles (metals) by sieving, and the final sludge obtained was stirred at $150 \mathrm{rpm}$ for $1 \mathrm{~h}$ to obtain uniform sludge in the liquid phase. Afterward,the processed sludge was introduced into two 1-L Erlenmeyer flasks sealed with stoppers.

\section{Selective Enrichment of SRB}

Selective enrichment of the active SRB cultures was attained by Postgate B medium (Postgate, 1984) that used lactate as the electron donor and carbon source. The main components of the medium were given as follows (in $\mathrm{g} / \mathrm{L}$ ): sodium lactate (3.5); $\mathrm{K}_{2} \mathrm{HPO}_{4}(0.5), \mathrm{NH}_{4} \mathrm{Cl}(1.0), \mathrm{FeSO}_{4} .7 \mathrm{H}_{2} \mathrm{O}(0.5), \mathrm{MgSO}_{4} .7 \mathrm{H}_{2} \mathrm{O}$ (2.0), $\mathrm{CaSO}_{4}$ (1.0), yeast extract (1.0), ascorbic acid (0.1), and thioglycolic acid (0.1). The culture was also supplemented with bromoethanesulfonic acid (BESA) (3.2 g/L) during the enrichment phase for inhibiting the methanogens that can consume the lactate medium. The $\mathrm{pH}$ of the growth medium at the start was kept at $7.5 \pm 0.1$ using $1 \mathrm{~N} \mathrm{NaOH}$ or $\mathrm{HCl}$ solution. Furthermore, the sterilization of the medium was carried out for $20 \mathrm{~min}$ at $15 \mathrm{psi}$ and $120^{\circ} \mathrm{C}$. Anaerobic conditions were maintained by purging $\mathrm{N}_{2}$ gas in the medium before inoculation. 1-L bottles were used for enrichment which were kept inside the incubator and were shaken using a rotary shaker at $120 \mathrm{rpm}$ and $30^{\circ} \mathrm{C}$. The enrichment was confirmed by the reduction of sulfate to sulfide, signified by change in the media color to black. The enrichment of SRB culture was further enhanced by subculturing every week using a fresh medium after decanting $70 \%$ of the supernatant from the culture bottle. After a period of 4 weeks, a culture potentially having a dense population of mixed SRBs was achieved. This enriched SRB culture was then used in MFCs. A non-enriched culture was used as the control.

\section{Assembly and Operation of the MFC}

Two-chamber MFC systems were employed in this research. Each anodic and cathodic chamber had a working volumetric capacity of $200 \mathrm{~mL}$. The anode used in the experimental work was $5-\mathrm{cm} \times 5-\mathrm{cm}$ carbon felt $(\mathrm{CF})$ (Alfa Aesar, United States) 
with $3.18 \mathrm{~mm}$ thickness or $\mathrm{CF}$ coated with $\mathrm{Fe}_{3} \mathrm{O}_{4}$, while platinum-fabricated carbon cloth was utilized as the cathode $\left(1.00 \mathrm{mg} \mathrm{cm}^{-2} 20 \mathrm{wt} \% \mathrm{Pt}(5 \times 5 \mathrm{~cm})\right.$; Fuel Cell Earth, Wakefield, United States). A minimum separation was ensured between the electrodes for reducing the internal resistance $\left(\mathrm{R}_{\text {int }}\right)$ using a proton $\left(\mathrm{H}^{+}\right)$exchange membrane (Nafion ${ }^{\circledR} 117$, Dupont Co., United States). The proton exchange membrane was treated with $\mathrm{H}_{2} \mathrm{O}_{2}$, sulfuric acid, and deionized water to improve MFC performance. The external resistor with an external resistance $\left(\mathrm{R}_{\text {ext }}\right)$ of $500 \Omega$ was used to complete the circuit by linking the electrodes. The temperature of the MFC system was sustained at $30^{\circ} \mathrm{C}$ using a water bath. The anolyte medium of tannery wastewater was diluted to the COD levels of $500 \mathrm{mg} / \mathrm{L}$ and $\mathrm{COD} / \mathrm{SO}_{4}{ }^{2-}$ of 2.0 by using nutrients with compositions as follows: $\mathrm{NaHCO}_{3}, 420 \mathrm{mg} \mathrm{L}^{-1}$; $\mathrm{CaCl}_{2}, 15 \mathrm{mg} \mathrm{L}^{-1}$; and $1 \mathrm{ml}$ of trace mineral solution. $\left(\mathrm{NH}_{4}\right)_{2} \mathrm{SO}_{4}, \mathrm{MgSO}_{4} .7 \mathrm{H}_{2} \mathrm{O}$, and $\mathrm{MnSO}_{4} \cdot \mathrm{H}_{2} \mathrm{O}$ were also added as nutrients to maintain consistent initial sulfate concentration. The MFC medium was sparged with nitrogen. A magnetic stirrer was used in the anodic chamber for stirring, and anaerobic conditions of the anodic chamber were maintained by purging $\mathrm{N}_{2}$ gas. In the cathodic chamber, $0.1 \mathrm{M}$ phosphate buffer with $\mathrm{pH} 7.0$ was added as the catholyte, and $\mathrm{O}_{2}$ (from air) was delivered via an air pump equipped with a regulator. Ports were provided to each chamber for feeding, withdrawing samples, and withdrawing the ultimate treated medium. For the MFC setup, 20\% sludge and $80 \%$ anolyte mixture were used to sustain the growth of the biofilm on the anodic electrode; $50 \%$ medium was decanted for the first three runs and superseded with sludge and fresh medium with the same ratio (1:4). After the third cycle, only the anolyte was added for subsequent cycles.

\section{Estimation of Electrochemical Performance}

The voltage was measured using a multimeter that was attached across the anodic and cathodic electrodes, and voltage data were monitored at regular intervals. The logged voltage (V) was

\section{A}

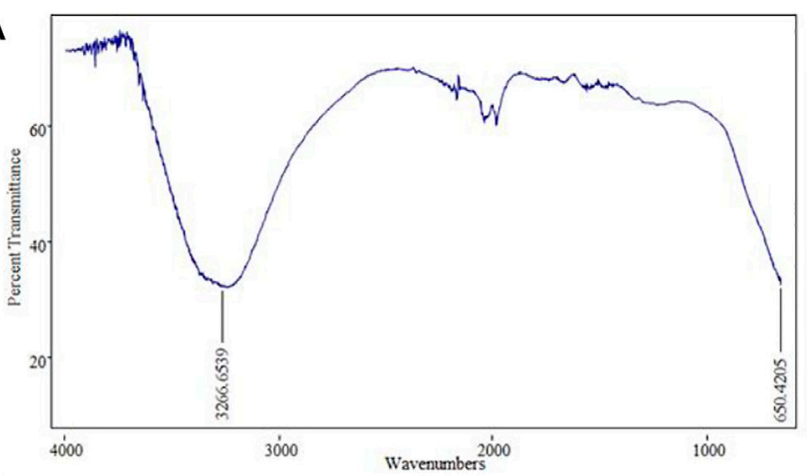

B

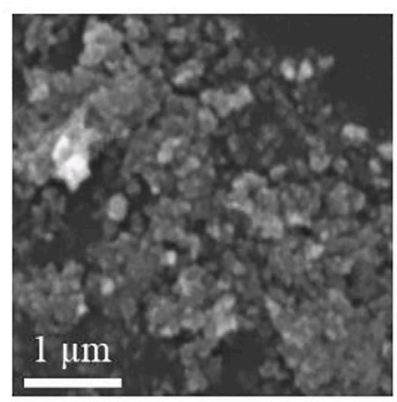

C
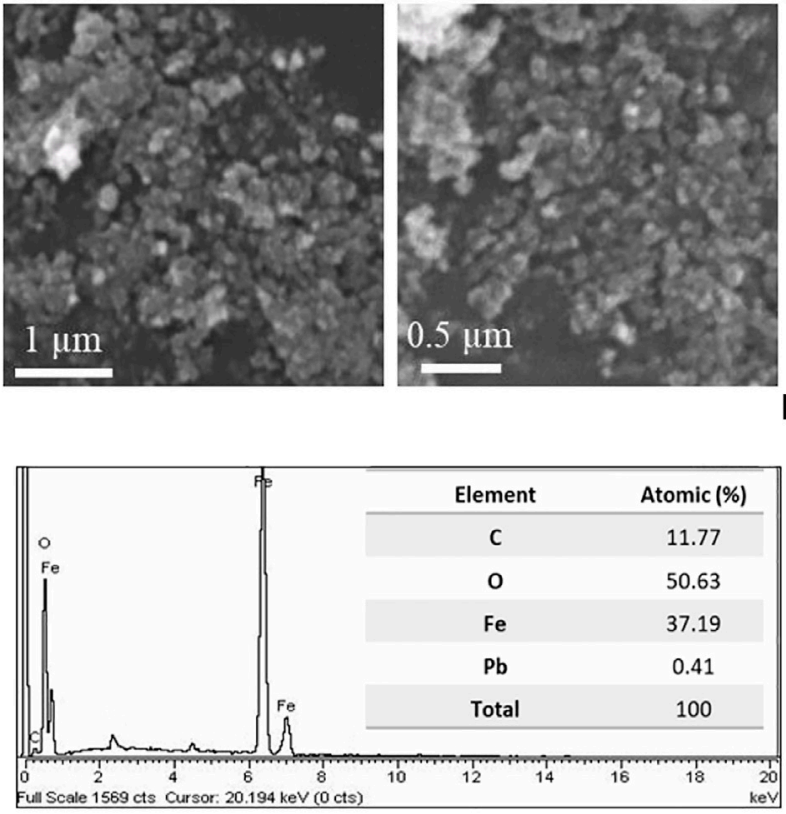

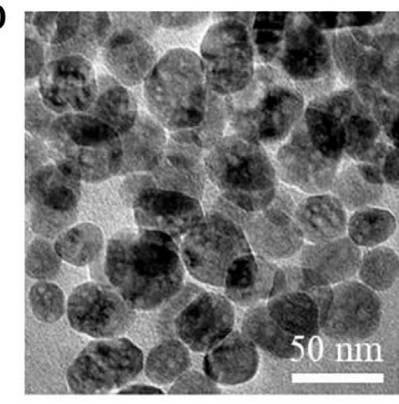

E (311)

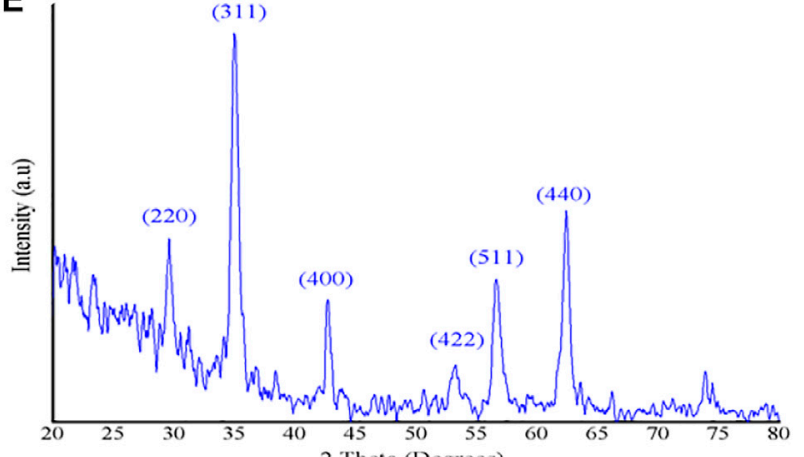

$\mathbf{F}$

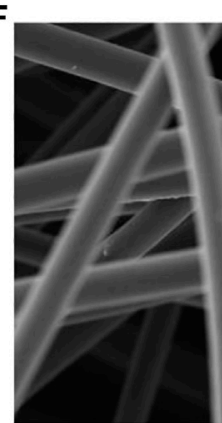

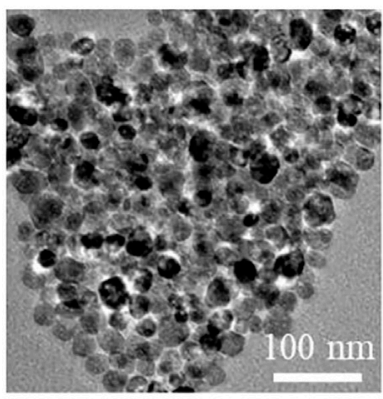
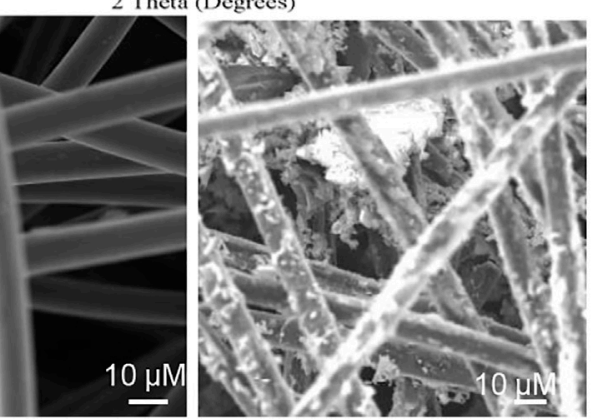

FIGURE 1 | $\mathrm{Fe}_{3} \mathrm{O}_{4}$ nanoparticle characterization and the CF-modified anode. (A) FT-IR spectrum of synthesized nanoparticles in the range of 4,000-600 $\mathrm{cm}^{-1}$. (B) SEM images of synthesized nanoparticles. (C) EDX for elemental analysis of synthesized nanoparticles, showing the atomic percentage of elements present. (D) TEM images of synthesized nanoparticles. (E) XRD patterns of Fe NPs. (F) SEM images of bare CF and iron particle-modified CF. 
utilized to calculate the current (I) using Ohm's law ( $\mathrm{I}=\mathrm{V} / \mathrm{R})$. The power density $(\mathrm{P})$, standardized to the anodic surface area facing the anodic chamber, was measured using the equation $\mathrm{P}=$ $\mathrm{V}^{2} /\left(\mathrm{R}_{\text {ext }} \cdot \mathrm{A}\right)$, where $\mathrm{A}\left(\mathrm{m}^{2}\right)=$ anodic surface area, $\mathrm{R}_{\text {ext }}(\Omega)=$ the external circuit resistance, and $\mathrm{V}$ [Volts] = MFC potential. By changing the $\mathrm{R}_{\text {ext }}$ step by step from $10 \mathrm{~K} \Omega$ to $10 \Omega$, the polarization curve was acquired. Every resistor was retained for $30 \mathrm{~min}$, and the voltage was stable.

COD (chemical oxygen demand) was calculated by the standard method reported previously (Greenberg et al., 1992). Percentage removal of COD was acquired by the following relation:

$$
\text { COD removal } \%=\frac{\left(\mathrm{COD}_{0}-\mathrm{COD}_{\mathrm{f}}\right)}{\mathrm{COD}_{f}}
$$

where $\mathrm{COD}_{0}$ and $\mathrm{COD}_{f}$ represent the $\mathrm{COD}$ measured at time $\mathrm{t}=0$ and final time $t=f$, respectively. Sulfates were measured using the standard APHA method.

The Coulombic efficiency (CE) of the MFC was estimated by the relation given as follows:

$$
\mathrm{CE} \%=\frac{8 \times \mathrm{I} \times \Delta \mathrm{t}}{\Delta \mathrm{COD} \times \mathrm{V}_{\text {an }} \times 96,485} \times 100 .
$$

Here, I (Amp) is the average current generated, $\Delta t(\mathrm{sec})$ is the time period for which the experiment was run, while the $\triangle \mathrm{COD}$ is the COD change from the initial value to the final value, $V_{\text {an }}(\mathrm{L})$ is the wastewater volume which has been treated in the anodic chamber, number 8 in the equation is the constant against M.W. of the oxygen molecule $(32 \mathrm{~g} / \mathrm{mol})$, and four electrons swapped per reduced oxygen molecule. Electrochemical experiments were repeated atleast twice $(n=2)$.

\section{RESULTS AND DISCUSSIONS}

\section{Iron Nanoparticle Characterization and CF-Modified Anode}

First, the characterization of synthesized Fe NPs was performed. The FT-IR spectrum of synthesized nanoparticles was obtained in the range of $4,000-600 \mathrm{~cm}^{-1}$ to elucidate the formation of the nanomaterial and its purity. Figure 1A shows the FT-IR spectrum of the subjected nanoparticles. Two main peaks at $3,266 \mathrm{~cm}^{-1}$ and at $650 \mathrm{~cm}^{-1}$ are obtained which corresponds to the $-\mathrm{OH}$ bond stretching vibration and $\mathrm{Fe}-\mathrm{O}$ bond vibrations, respectively. The FT-IR spectrum of the synthesized nanoparticles was in alignment with previously reported studies (Mishra et al., 2014; Touqeer et al., 2020). The morphology and surface of the synthesized nanoparticles was elucidated by SEM, as shown in Figure 1B. SEM images at different magnification levels exhibit that nanoparticles of very small size and uniform spherical morphology have been produced through a hydrothermal process. Few clumps/ aggregations were also observed in the SEM images which might be due the magnetic character of $\mathrm{Fe}_{3} \mathrm{O}_{4}$ nanoparticles. Since the purity and morphology of the nanomaterial are crucial factors which could affect the cell performance, the elemental analysis of synthesized nanoparticles was done through the EDX. The purity and percentage composition of elements were obtained by the EDX plot, which is presented in Figure 1C. The atomic percentage of nanoparticles obtained by EDX is given in the table of Figure 1C. The ratio between atomic percentages of iron and $\mathrm{O}_{2}$ is similar to the atomic ratio of iron and $\mathrm{O}_{2}$ in $\mathrm{Fe}_{3} \mathrm{O}_{4}$, which affirms the formation of $\mathrm{Fe}_{3} \mathrm{O}_{4}$ nanoparticles. The morphology of nanoparticles was also determined by TEM using an accelerating voltage of $200 \mathrm{kV}$. From Figure 1D at different magnifications, one can clearly see a homogeneous morphology of $\mathrm{Fe}_{3} \mathrm{O}_{4}$ nanoparticles. The particles were somehow agglomerated due to the magnetic behavior of the nanoparticles. Furthermore, nanoparticles were spherical in nature with the appearance of mesopores in them which can be seen from the TEM images. The crystallinity and phase angle of the nanoparticles were estimated by XRD. The XRD plot of the synthesized nanoparticles is in good agreement with magnetite

\section{A}

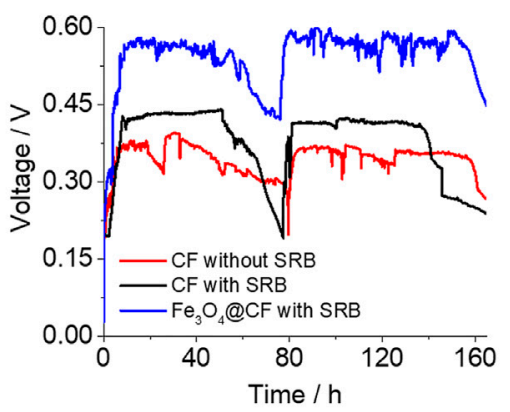

B

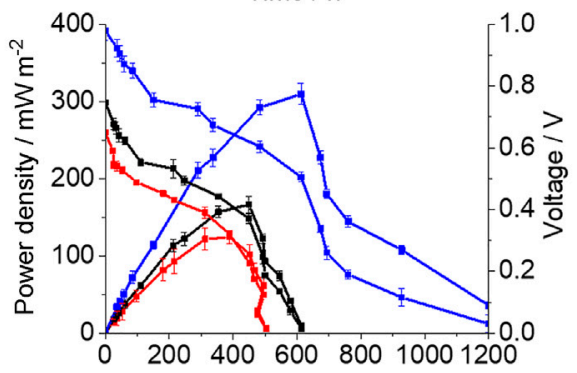

C Current density / $\mathrm{mA} \mathrm{m}^{-2}$

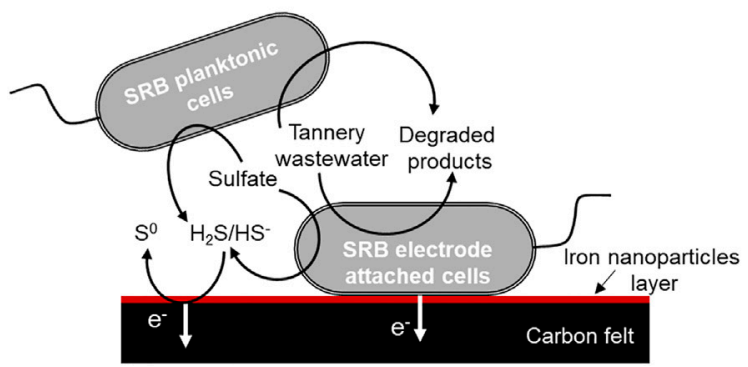

FIGURE 2 | Voltage generation, power density curves, and predicted pathway involved in current generation. (A) Voltage generation by tannery wastewater of $500 \mathrm{mg} / \mathrm{L}$ COD strength for different MFC systems. (B) Polarization and power density curves for different electrode and culture conditions obtained by varying circuit resistance. (C) Proposed mechanism for simultaneous bioelectricity generation, tannery wastewater degradation, and sulfate reduction. 
TABLE 2 | Comparison of MFC performance for different anode-modified electrodes.

\begin{tabular}{|c|c|c|c|c|c|c|}
\hline Modified anode & $\begin{array}{l}\text { Type of } \\
\text { MFC }\end{array}$ & $\begin{array}{l}\text { Methods for } \\
\text { modification }\end{array}$ & $\begin{array}{c}\text { Power } \\
\text { density } \\
\left(\mathrm{mW} / \mathrm{m}^{2}\right)\end{array}$ & Inoculum source & $\begin{array}{l}\text { Energy } \\
\text { source }\end{array}$ & References \\
\hline $\begin{array}{l}\text { Reduced graphene oxide/MnO2 } \\
\text { composite/carbon felt }\end{array}$ & $\begin{array}{l}\text { Two- } \\
\text { chamber }\end{array}$ & Electrode position & 2065 & $\begin{array}{l}\text { Pre-acclimatized microbes } \\
\text { from other reactors }\end{array}$ & Acetate & $\begin{array}{l}\text { Zhang et al. } \\
\text { (2016) }\end{array}$ \\
\hline Polyaniline (PANI)/CF & $\begin{array}{l}\text { Two- } \\
\text { chamber }\end{array}$ & In situ polymerization & 27.3 & Anaerobic & Acetate & Li et al. (2011) \\
\hline Tartaric acid-doped PANI/carbon cloth & $\begin{array}{l}\text { Two- } \\
\text { chamber }\end{array}$ & In situ polymerization & 490 & S. oneidensis & Lactate & Liao et al. (2015) \\
\hline Graphene/PANI/carbon cloth & $\begin{array}{l}\text { Two- } \\
\text { chamber }\end{array}$ & Electrochemical & 1,390 & Anaerobic sludge & Acetate & Hou et al. (2013) \\
\hline PANI-carbon nanotubes/graphite felt & $\begin{array}{l}\text { Two- } \\
\text { chamber }\end{array}$ & Electropolymerization & 257 & S. putrefaciens & Acetate & Cui et al. (2015) \\
\hline Carbon nanotubes/PANI/nickel foams & $\begin{array}{l}\text { Single- } \\
\text { chamber }\end{array}$ & Mechanical coating & 42 & E. coli & Glucose & Qiao et al. (2007) \\
\hline $\begin{array}{l}\text { Polypyrrole (PPy)/anthraquinone-2,6- } \\
\text { disulfonic disodium salt/carbon felt }\end{array}$ & $\begin{array}{l}\text { Two- } \\
\text { chamber }\end{array}$ & Electropolymerization & 1,300 & S. decolorationis & Lactic acid & Feng et al. (2010) \\
\hline PPy/carbon nanotubes $/ \mathrm{MnO}_{2}$ & $\begin{array}{l}\text { Two- } \\
\text { chamber }\end{array}$ & Electropolymerization & $1,125.4$ & Mixed sewage culture & $\begin{array}{l}\text { Sewage } \\
\text { wastewater }\end{array}$ & $\begin{array}{l}\text { Mishra and Jain, } \\
\text { (2016) }\end{array}$ \\
\hline Iron oxide/carbon felt & $\begin{array}{l}\text { Two- } \\
\text { chamber }\end{array}$ & Deposition coating & 309 & Mixed SRB & $\begin{array}{l}\text { Tannery } \\
\text { wastewater }\end{array}$ & This study \\
\hline
\end{tabular}

JPCDS Card No 019-0629. The obtained two theta values attribute to the hkl values of (220), (311), (400), (422), 511), and (440), respectively (Figure 1E). The sharp peaks and absence of any extraneous peaks affirms the purity and high crystallinity of the subjected nanoparticles, respectively. The crystal shape corresponding to the identified peaks (JPCDS Card No 019-0629) is a cubic spinel shape. The results obtained by XRD analysis match with that of previously reported results by other researchers (Xing et al., 2021). Once the nanoparticle synthesis was confirmed, it was coated on CF using the dip-anddry method. Since surface properties of electrodes can substantially influence the operation of MFCs, especially bacterial growth and its adhesion to the electrodes ( $Y u$ et al., 2017), SEM analysis was conducted to confirm the morphology of the modified anode surface (Figure 1F). The images produced by SEM clearly revealed very smooth and clean fibers in the unmodified CF electrode. Conversely, a much irregular and rougher fiber surface in the modified electrode was observed, indicating that the presence of iron particles on the CF structures ( $\mathrm{Fe}_{3} \mathrm{O}_{4} @ \mathrm{CF}$ anode) promotes roughness on the CF electrodes. It is well-known that a rough surface assists additional microbial adhesion/colonization and ultimately enhanced electron transfer (Quan et al., 2015).

\section{Bioelectricity With Electroactive SRB and an $\mathrm{Fe}_{3} \mathrm{O}_{4} @ \mathrm{CF}$ Electrode}

Voltage production by MFCs with the non-SRB-enriched CF electrode, SRB-enriched CF electrode, and SRB-enriched $\mathrm{Fe}$ NP-modified CF electrode $\left(\mathrm{Fe}_{3} \mathrm{O}_{4} @ \mathrm{CF}\right.$ electrode $)$ was compared. Non-enriched and SRB-enriched bacteria were added to the respective MFCs. The microbial attachment and development of the biofilm on the electrode surface of the anodic chamber took place, and relatively stable voltage was generated (at $500 \Omega$ ) in the fourth week of MFC operation with tannery wastewater as the electron donor (at $\mathrm{COD} / \mathrm{SO}_{4}{ }^{2-}$ of 2.0 ) in all cases (Figure 2A). In the fed batches, once the electron donors had been substantially consumed, the voltage started to decline and then attained the stable state again after the addition of fresh anolyte containing tannery wastewater, nutrients, and sulfate. In comparison to SRB non-enriched culture CF (0.39 V), SRBenriched CF produced almost $15 \%$ higher voltage $(0.45 \mathrm{~V})$ (Figure 2A), suggesting the presence of more electroactive bacteria. A further substantial increase in voltage production was observed in the case of the SRB-enriched $\mathrm{Fe}_{3} \mathrm{O}_{4} @ \mathrm{CF}$ electrode that was 1.53 times greater than the control without SRB-enriched culture and CF only (Figure 1A). This strongly suggests that the $\mathrm{Fe}_{3} \mathrm{O}_{4} @ \mathrm{CF}$ electrode promotes electron transfer to the anode likely due to higher conductivity of $\mathrm{Fe}_{3} \mathrm{O}_{4}$ which can be used as conduit by SRB-like biogenic iron compounds (Murugan et al., 2018). At a tannery wastewater strength of $500 \mathrm{mg} / \mathrm{L}(\mathrm{COD})$ and $\mathrm{COD} / \mathrm{SO}_{4}{ }^{2-}$ ratio of 2.0 , a maximum power density and corresponding current density achieved were $124 \pm 8 \mathrm{~mW} / \mathrm{m}^{2}$ and $388 \pm 24 \mathrm{~mA} / \mathrm{m}^{2}$, respectively, obtained from power and polarization curves (Figure $2 \mathbf{B}$ ). The achieved CE percentage was $24.6 \%$, and the $\mathrm{R}_{\text {int }}$ calculated on the basis of the slope curve technique was $330 \Omega$. In comparison, while a maximum power density and corresponding current density achieved with SRB-enriched CF were $166 \pm 11 \mathrm{~mW} / \mathrm{m}^{2}$ and $449 \pm 24 \mathrm{~mA} / \mathrm{m}^{2}$, respectively, they were $309 \pm 13 \mathrm{~mW} / \mathrm{m}^{2}$ and $612 \pm 25 \mathrm{~mA} / \mathrm{m}^{2}$, respectively, for the SRB-enriched $\mathrm{Fe}_{3} \mathrm{O}_{4} @$ $\mathrm{CF}$ electrode, clearly indicating the significance of electrode modification for enhancing maximum power density. Moreover, the enhanced power output suggested better bacterial growth and attachment on the $\mathrm{Fe}_{3} \mathrm{O}_{4} @ \mathrm{CF}$ anode. Such facts have been reported in previous studies, where current generation enhancement was correlated with the bacterial biofilm growth (Reguera et al., 2006). Since in the mixed microbial community, many different microbes can play different roles including organic degradation and direct 
or mediated transfer of electrons from microbes to the electrode surface, the advantage associated with the presence of SRB is to outcompete methanogens that result in the suppression of $\mathrm{CH}_{4}$ formation in SRB-enriched cultures (Dar et al., 2008), and hence, improved MFC performance can be achieved as more electrons are available for transfer to electrodes. While electrons are transferred to the anode either directly via electrogens by c-type cytochrome or electrically conductive pili (nanowires), or indirectly via redox mediators (Lovley and Nevin, 2011), the SRB group also comprised species having c-type cytochromes that aid in DET to the anode, excluding the requirements of an exterior mediator (Kang et al., 2014). Apparently, there is a disadvantage linked with SRBs as part of the electron produced in the MFC was consumed for sulfate reduction, but the presence of continuous electron donors in real wastewater systems can help surmount this drawback to a considerable extent. Given that sulfates are reduced to sulfides by SRBs in the MFC, sulfides can be further oxidized to elemental sulfur and eventually assist in electricity production. Sulfide oxidation for current generation has already been wellinvestigated while treating sulfate-/sulfide-rich wastewater using SRBs (Lee et al., 2014). The soluble mediator-like sulfides allow all cells to contribute to current generation whether they are located in the biofilm or in the planktonic phase, and hence, planktonic cells may also play an important role in overall current generation. Based on the results, main possible steps encompassed in electricity generation, tannery wastewater biodegradation, and sulfate removal in this wotk are shown in Figure 2C. A comparison of MFC performance for different anode modified electrodes is also provided in Table 2 .

\section{Tannery Wastewater Treatment Performance}

MFC performance in relation to COD removal and sulfate reduction was evaluated in all three MFC systems. A consistent initial COD and sulfate concentration were maintained at $500 \mathrm{mg} / \mathrm{L}$ and $250 \mathrm{mg} / \mathrm{L}$, respectively, in all these MFCs. The removal percentage was observed for $72 \mathrm{~h}$ by taking samples after intervals of $12 \mathrm{~h}$. A $53 \pm 3.1 \%$ COD removal was achieved in the current study with non-SRB-enriched CF (Figure 3A). In comparison, SRB-enriched CF showed $10 \%$ higher COD removal $(63 \pm 3.6 \%)$, indicating the importance of SRB in degrading complex compounds in tannery wastewater. Nevertheless, COD removal was further enhanced with the SRBenriched $\mathrm{Fe}_{3} \mathrm{O}_{4} @ \mathrm{CF}$ electrode where $75 \pm 2.1 \% \mathrm{COD}$ removal was accomplished (Figure 3A). The accelerated biodegradation of tannery wastewater in the MFCs with SRB enriched- $\mathrm{Fe}_{3} \mathrm{O}_{4} @ \mathrm{CF}$ can be attributed to the anode electrode which provides a pathway for electron transfer to the cathode via an external circuit that can eventually boost the metabolic rate of microbes in the presence of these non-exhaustible electron acceptors (Mohanakrishna et al., 2020; Hu et al., 2018). Furthermore, the improvement in tannery wastewater biodegradation rates attributed to SRB cultures suggests the enrichment of microbes which were highly specific to the biodegradation of recalcitrant pollutants in tannery wastewater. SRB cultures performing more specific and efficient functions in anaerobic systems have already been shown in previous studies. In terms of sulfate reduction, a similar trend was observed as with COD removal. Highest sulfate removal was demonstrated by the MFC with SRBenriched $\mathrm{Fe}_{3} \mathrm{O}_{4} @ \mathrm{CF}(88 \pm 4.1 \%)$, followed by SRB-enriched CF $(78 \pm 2.6 \%)$ and non-SRB-enriched CF $(51 \pm 3.7 \%)$ (Figure 3B). While theoretical calculations showed that the $\mathrm{COD} / \mathrm{SO}_{4}{ }^{2-}$ ratio of 0.67 is sufficient for completely removing the organics (as COD) by SRBs during sulfate reduction (Rasool et al., 2015), it was reported earlier that in real systems, a COD/ $\mathrm{SO}_{4}{ }^{2-}$ ratio of $1.7-2.5$ is optimum for microbial growth while reducing sulfates in fed batches in the presence of SRBs (Miran et al., 2018). Therefore, in this study, an optimal concentration of $\mathrm{COD} / \mathrm{SO}_{4}{ }^{2-}$ ratio of 2.0 was selected to avoid any limitations as a low $\mathrm{COD} / \mathrm{SO}_{4}{ }^{2-}$ ratio can result in inferior MFC performance, as reported by Ghangrekar et al. (Ghangrekar et al., 2010).

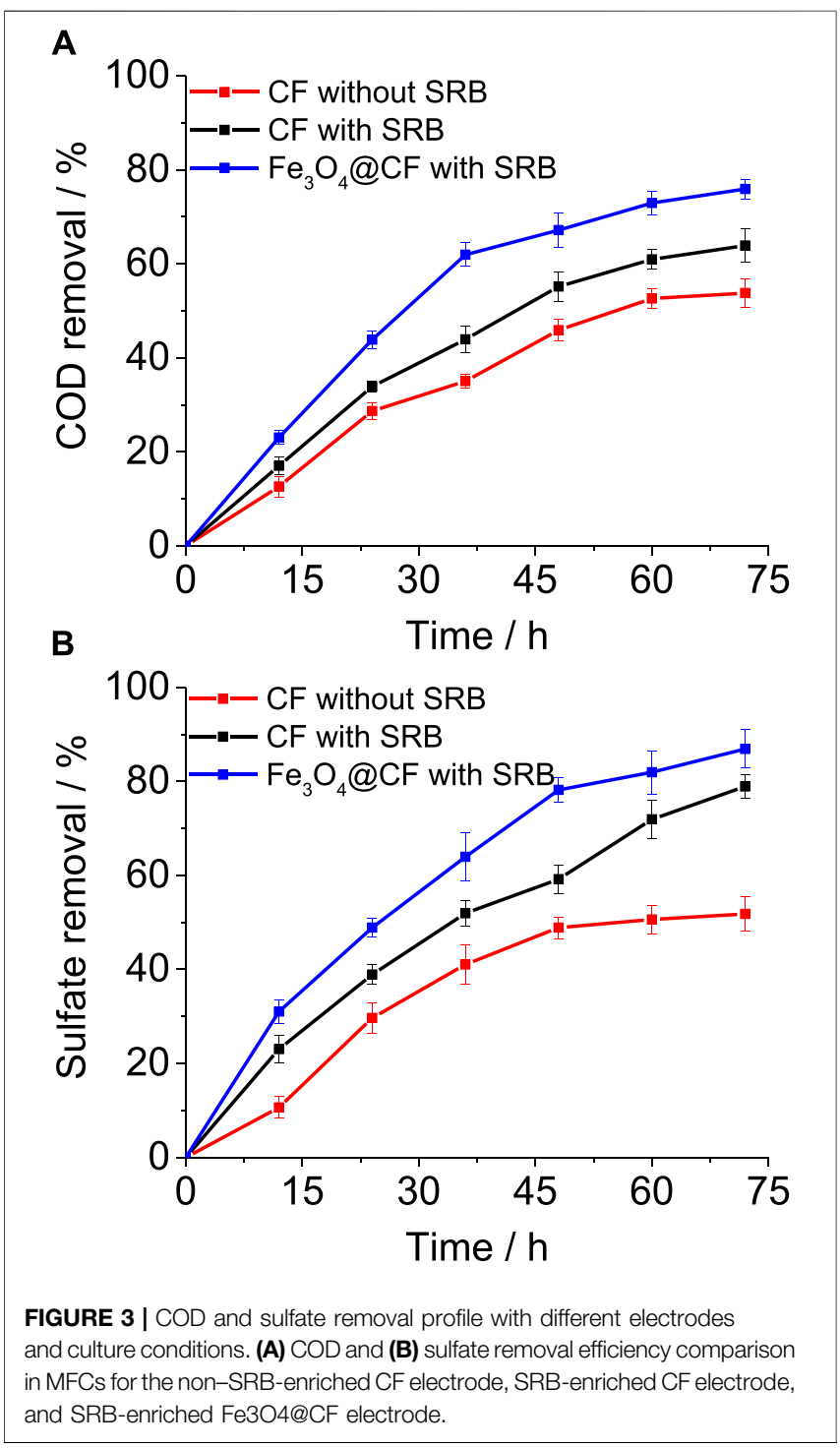


Furthermore, good repeatability of MFC cycles in this work indicates the robustness of electroactive SRB for COD and sulfate removal.

\section{CONCLUSION}

Fe NP-modified CF with mixed SRB cultures can be utilized in MFCs for tannery wastewater treatment with simultaneous sulfate removal and electricity production. An effective tannery wastewater treatment was demonstrated that is beneficial for resolving environmental and local societal issues. Although power output with the modified electrode and SRBs improved substantially, the tannery wastewater biodegradation rate can be further enhanced by quantifying the type of microbial culture present and further fine-tuning their relative abundance. For commercial purposes, there is a requirement of further modification and optimization of MFC designs and

\section{REFERENCES}

Bhalli, J. A., and Khan, Q. M. (2006). Pollution Level Analysis in Tannery Effluents Collected from Three Different Cities of Punjab, Pakistan. Pakistan J. Biol. Sci. 9, 418-421. doi:10.3923/pjbs.2006.418.421

Chen, B.-Y., Ma, C.-M., Han, K., Yueh, P.-L., Qin, L.-J., and Hsueh, C.-C. (2016). Influence of Textile Dye and Decolorized Metabolites on Microbial Fuel CellAssisted Bioremediation. Bioresour. Techn. 200, 1033-1038. doi:10.1016/ j.biortech.2015.10.011

Choudhury, P., Prasad Uday, U. S., Bandyopadhyay, T. K., Ray, R. N., and Bhunia, B. (2017). Performance Improvement of Microbial Fuel Cell (MFC) Using Suitable Electrode and Bioengineered Organisms: A Review. Bioengineered 8, 471-487. doi:10.1080/21655979.2016.1267883

Cui, H.-F., Du, L., Guo, P.-B., Zhu, B., and Luong, J. H. T. (2015). Controlled Modification of Carbon Nanotubes and Polyaniline on Macroporous Graphite Felt for High-Performance Microbial Fuel Cell Anode. J. Power Sourc. 283, 46-53. doi:10.1016/j.jpowsour.2015.02.088

Dar, S. A., Kleerebezem, R., Stams, A. J. M., Kuenen, J. G., and Muyzer, G. (2008). Competition and Coexistence of Sulfate-Reducing Bacteria, Acetogens and Methanogens in a Lab-Scale Anaerobic Bioreactor as Affected by Changing Substrate to Sulfate Ratio. Appl. Microbiol. Biotechnol. 78, 1045-1055. doi:10.1007/s00253-008-1391-8

Durai, G., and Rajasimman, M. (2011). Biological Treatment of Tannery Wastewater-A Review. J. Environ. Sci. Techn. 4, 1-17. doi:10.3923/jest.2011.1.17

Feng, C., Ma, L., Li, F., Mai, H., Lang, X., and Fan, S. (2010). A Polypyrrole/ anthraquinone-2,6-Disulphonic Disodium Salt (PPy/AQDS)-modified Anode to Improve Performance of Microbial Fuel Cells. Biosens. Bioelectron. 25, 1516-1520. doi:10.1016/j.bios.2009.10.009

Galiana-Aleixandre, M.-V., Mendoza-Roca, J.-A., and Bes-Piá, A. (2011). Reducing Sulfates Concentration in the Tannery Effluent by Applying Pollution Prevention Techniques and Nanofiltration. J. Clean. Prod. 19, 91-98. doi:10.1016/j.jclepro.2010.09.006

Ghangrekar, M. M., Murthy, S. S. R., Behera, M., and Duteanu, N. (2010). Effect of Sulfate Concentration in the Wastewater on Microbial Fuel Cell Performance. Environ. Eng. Manag. J. 9, 1227-1234. doi:10.30638/eemj.2010.159

Greenberg, A. E., Clesceri, L. S., and Eaton, A. D. (1992). Standard Methods for Examination of Water and Wastewater. Washington DC: American Public Health Association.

Gu, Y., Li, Y., Li, X., Luo, P., Wang, H., Wang, X., et al. (2017). Energy SelfSufficient Wastewater Treatment Plants: Feasibilities and Challenges. Energ. Proced. 105, 3741-3751. doi:10.1016/j.egypro.2017.03.868

Habermann, W., and Pommer, E. H. (1991). Biological Fuel Cells with Sulphide Storage Capacity. Appl. Microbiol. Biotechnol. 35, 128-133. doi:10.1007/ bf00180650 operation. For instance, a continuous system is required to be developed and optimized for industrially acceptable performance.

\section{DATA AVAILABILITY STATEMENT}

The raw data supporting the conclusion of this article will be made available by the authors, without undue reservation.

\section{AUTHOR CONTRIBUTIONS}

MM and HM conceived the idea; MM supervised the study; FM conducted experiments and wrote the manuscript; HM performed microbial analysis, SA conducted some analysis and helped in writing the manuscript, and MM and HM reviewed the article.

Hassan, H., Jin, B., Donner, E., Vasileiadis, S., Saint, C., and Dai, S. (2018). Microbial Community and Bioelectrochemical Activities in MFC for Degrading Phenol and Producing Electricity: Microbial Consortia Could Make Differences. Chem. Eng. J. 332, 647-657. doi:10.1016/j.cej.2017.09.114

Hou, J., Liu, Z., and Zhang, P. (2013). A New Method for Fabrication of Graphene/ polyaniline Nanocomplex Modified Microbial Fuel Cell Anodes. J. Power Sourc. 224, 139-144. doi:10.1016/j.jpowsour.2012.09.091

Hu, J., Zhang, Q., Lee, D.-J., and Ngo, H. H. (2018). Feasible Use of Microbial Fuel Cells for Pollution Treatment. Renew. Energ. 129, 824-829. doi:10.1016/ j.renene.2017.02.001

Hussain, A., Hasan, A., Javid, A., and Qazi, J. I. (2016). Exploited Application of Sulfate-Reducing Bacteria for Concomitant Treatment of Metallic and Nonmetallic Wastes: a Mini Review. 3 Biotech. 6, 119. doi:10.1007/s13205-0160437-3

Kang, C. S., Eaktasang, N., Kwon, D.-Y., and Kim, H. S. (2014). Enhanced Current Production by Desulfovibrio Desulfuricans Biofilm in a Mediator-Less Microbial Fuel Cell. Bioresour. Technol. 165, 27-30. doi:10.1016/ j.biortech.2014.03.148

Lee, D.-J., Lee, C.-Y., and Chang, J.-S. (2012). Treatment and Electricity Harvesting from Sulfate/sulfide-Containing Wastewaters Using Microbial Fuel Cell with Enriched Sulfate-Reducing Mixed Culture. J. Hazard. Mater. 243, 67-72. doi:10.1016/j.jhazmat.2012.09.071

Lee, D.-J., Liu, X., and Weng, H.-L. (2014). Sulfate and Organic Carbon Removal by Microbial Fuel Cell with Sulfate-Reducing Bacteria and Sulfide-Oxidising Bacteria Anodic Biofilm. Bioresour. Techn. 156, 14-19. doi:10.1016/ j.biortech.2013.12.129

Li, C., Zhang, L., Ding, L., Ren, H., and Cui, H. (2011). Effect of Conductive Polymers Coated Anode on the Performance of Microbial Fuel Cells (MFCs) and its Biodiversity Analysis. Biosens. Bioelectron. 26, 4169-4176. doi:10.1016/ j.bios.2011.04.018

Liao, Z.-H., Sun, J.-Z., Sun, D.-Z., Si, R.-W., and Yong, Y.-C. (2015). Enhancement of Power Production with Tartaric Acid Doped Polyaniline Nanowire Network Modified Anode in Microbial Fuel Cells. Bioresour. Techn. 192, 831-834. doi:10.1016/j.biortech.2015.05.105

Lovley, D. R., and Nevin, K. P. (2011). A Shift in the Current: New Applications and Concepts for Microbe-Electrode Electron Exchange. Curr. Opin. Biotechnol. 22, 441-448. doi:10.1016/j.copbio.2011.01.009

Luderer, G., Pehl, M., Arvesen, A., Gibon, T., Bodirsky, B. L., De Boer, H. S., et al. (2019). Environmental Co-benefits and Adverse Side-Effects of Alternative Power Sector Decarbonization Strategies. Nat. Commun. 10, 5229. doi:10.1038/ s41467-019-13067-8

Maktabifard, M., Zaborowska, E., and Makinia, J. (2018). Achieving Energy Neutrality in Wastewater Treatment Plants through Energy Savings and Enhancing Renewable Energy Production. Rev. Environ. Sci. Biotechnol. 17, 655-689. doi:10.1007/s11157-018-9478-x 
Malvankar, N. S., King, G. M., and Lovley, D. R. (2015). Centimeter-long Electron Transport in marine Sediments via Conductive Minerals. ISME J. 9, 527-531. doi:10.1038/ismej.2014.131

Miran, W., Jang, J., Nawaz, M., Shahzad, A., and Lee, D. S. (2018). Sulfate-reducing Mixed Communities with the Ability to Generate Bioelectricity and Degrade Textile Diazo Dye in Microbial Fuel Cells. J. Hazard. Mater. 352, 70-79. doi:10.1016/j.jhazmat.2018.03.027

Mishra, D., Arora, R., Lahiri, S., Amritphale, S. S., and Chandra, N. (2014). Synthesis and Characterization of Iron Oxide Nanoparticles by Solvothermal Method. Prot. Met. Phys. Chem. Surf. 50, 628-631. doi:10.1134/s2070205114050128

Mishra, P., and Jain, R. (2016). Electrochemical Deposition of MWCNT-MnO2/ PPy Nano-Composite Application for Microbial Fuel Cells. Int. J. Hydrogen Energ. 41. doi:10.1016/j.ijhydene.2016.09.020

Mohanakrishna, G., Abu-Reesh, I. M., and Pant, D. (2020). Enhanced Bioelectrochemical Treatment of Petroleum Refinery Wastewater with Labaneh Whey as Co-substrate. Sci. Rep. 10, 19665. doi:10.1038/s41598-02076668-0

Murugan, M., Miran, W., Masuda, T., Lee, D. S., and Okamoto, A. (2018). Biosynthesized Iron Sulfide Nanocluster Enhanced Anodic Current Generation by Sulfate Reducing Bacteria in Microbial Fuel Cells. ChemElectroChem 5, 4015-4020. doi:10.1002/celc.201801086

Nakamura, R., Okamoto, A., Tajima, N., Newton, G. J., Kai, F., Takashima, T., et al. (2010). Biological Iron-Monosulfide Production for Efficient Electricity Harvesting from a Deep-Sea Metal-Reducing Bacterium. Chem. Eur. J. Chem. Bio. 11, 643-645. doi:10.1002/cbic.200900775

Postgate, J. R. (1984). The Sulfate-Reducing Bacteria. 2 edn.. UK: Cambridge University Press.

Qiao, Y., Li, C. M., Bao, S.-J., and Bao, Q.-L. (2007). Carbon Nanotube/polyaniline Composite as Anode Material for Microbial Fuel Cells. J. Power Sourc. 170, 79-84. doi:10.1016/j.jpowsour.2007.03.048

Quan, X., Sun, B., and Xu, H. (2015). Anode Decoration with Biogenic Pd Nanoparticles Improved Power Generation in Microbial Fuel Cells. Electrochim. Acta 182, 815-820. doi:10.1016/j.electacta.2015.09.157

Rafique, U., Ashraf, A., Khan, A. K., Nasreen, S., and Rashid, R. (2010). Toxic Chromium from Tanneries Pollute Water Resources and Soils of Sialkot (Pakistan). J. Chem. Soc. Pakistan 32, 644-649.

Rasool, K., Mahmoud, K. A., and Lee, D. S. (2015). Influence of Co-substrate on Textile Wastewater Treatment and Microbial Community Changes in the Anaerobic Biological Sulfate Reduction Process. J. Hazard. Mater. 299, 453-461. doi:10.1016/j.jhazmat.2015.07.044

Rasool, K., Woo, S. H., and Lee, D. S. (2013). Simultaneous Removal of COD and Direct Red 80 in a Mixed Anaerobic Sulfate-Reducing Bacteria Culture. Chem. Eng. J. 223, 611-616. doi:10.1016/j.cej.2013.03.031

Reguera, G., Nevin, K. P., Nicoll, J. S., Covalla, S. F., Woodard, T. L., and Lovley, D. R. (2006). Biofilm and Nanowire Production Leads to Increased Current in Geobacter Sulfurreducens Fuel Cells. Appl. Environ. Microbiol. 72, 7345-7348. doi:10.1128/aem.01444-06

Sun, D., Shao, S., Zhang, Y., Yang, Q., Hou, H., and Quan, X. (2020). Integrated Analysis of the Water-Energy-Environmental Pollutant Nexus in the Petrochemical Industry. Environ. Sci. Technol. 54, 14830-14842. doi:10.1021/ acs.est.9b07467

Thanikaivelan, P., Rao, J. R., Nair, B. U., and Ramasami, T. (2004). Progress and Recent Trends in Biotechnological Methods for Leather Processing. Trends Biotechnol. 22, 181-188. doi:10.1016/j.tibtech.2004.02.008

Touqeer, T., Mumtaz, M. W., Mukhtar, H., Irfan, A., Akram, S., Shabbir, A., et al. (2020). Fe3O4-PDA-Lipase as Surface Functionalized Nano Biocatalyst for the
Production of Biodiesel Using Waste Cooking Oil as Feedstock: Characterization and Process Optimization. Energies 13, 177. doi:10.3390/ en 13010177

Willis, C. L., Cummings, J. H., Neale, G., and Gibson, G. R. (1997). Nutritional Aspects of Dissimilatory Sulfate Reduction in the Human Large Intestine. Curr. Microbiol. 35, 294-298. doi:10.1007/s002849900257

Xing, Z., Dai, X., Wu, P., Zhang, C., Li, F., Xiao, Y., et al. (2021). Fe3O4@PDA Immobilized Glycerine Dehydrogenase. IOP Conf. Ser. Earth Environ. Sci. 651, 022026. doi:10.1088/1755-1315/651/2/022026

Yaqoob, A. A., Ibrahim, M. N. M., Umar, K., Parveen, T., Ahmad, A., Lokhat, D., et al. (2021). A Glimpse into the Microbial Fuel Cells for Wastewater Treatment with Energy Generation. Desalination Water Treat. 214, 379-389. doi:10.5004/dwt.2021.26737

Yaqoob, A. A., Khatoon, A., Mohd Setapar, S. H., Umar, K., Parveen, T., Mohamad Ibrahim, M. N., et al. (2020). Outlook on the Role of Microbial Fuel Cells in Remediation of Environmental Pollutants with Electricity Generation. Catalysts 10, 819. doi: $10.3390 /$ catal10080819

Yu, L., Yuan, Y., Tang, J., and Zhou, S. (2017). Thermophilic Moorella Thermoautotrophica -immobilized Cathode Enhanced Microbial Electrosynthesis of Acetate and Formate from CO 2. Bioelectrochemistry 117, 23-28. doi:10.1016/j.bioelechem.2017.05.001

Zhang, B., Zhao, H., Shi, C., Zhou, S., and Ni, J. (2009). Simultaneous Removal of Sulfide and Organics with Vanadium(V) Reduction in Microbial Fuel Cells. J. Chem. Technol. Biotechnol. 84, 1780-1786. doi:10.1002/jctb.2244

Zhang, C., Liang, P., Yang, X., Jiang, Y., Bian, Y., Chen, C., et al. (2016). Binder-free Graphene and Manganese Oxide Coated Carbon Felt Anode for HighPerformance Microbial Fuel Cell. Biosens. Bioelectron. 81, 32-38. doi:10.1016/j.bios.2016.02.051

Zhang, X., Zhang, D., Huang, Y., Wu, S., and Lu, P. (2020). The Anodic Potential Shaped a Cryptic Sulfur Cycling with Forming Thiosulfate in a Microbial Fuel Cell Treating Hydraulic Fracturing Flowback Water. Water Res. 185, 116270. doi:10.1016/j.watres.2020.116270

Zhang, Z., Guo, L., Wang, Y., Zhao, Y., She, Z., Gao, M., et al. (2020). Application of Iron Oxide (Fe3O4) Nanoparticles during the Two-Stage Anaerobic Digestion with Waste Sludge: Impact on the Biogas Production and the Substrate Metabolism. Renew. Energ. 146, 2724-2735. doi:10.1016/j.renene.2019.08.078

Zhou, C., Vannela, R., Hayes, K. F., and Rittmann, B. E. (2014). Effect of Growth Conditions on Microbial Activity and Iron-Sulfide Production by Desulfovibrio Vulgaris. J. Hazard. Mater. 272, 28-35. doi:10.1016/j.jhazmat.2014.02.046

Conflict of Interest: The authors declare that the research was conducted in the absence of any commercial or financial relationships that could be construed as a potential conflict of interest.

Publisher's Note: All claims expressed in this article are solely those of the authors and do not necessarily represent those of their affiliated organizations, or those of the publisher, the editors, and the reviewers. Any product that may be evaluated in this article, or claim that may be made by its manufacturer, is not guaranteed or endorsed by the publisher.

Copyright (C) 2021 Miran, Mumtaz, Mukhtar and Akram. This is an open-access article distributed under the terms of the Creative Commons Attribution License (CC BY). The use, distribution or reproduction in other forums is permitted, provided the original author(s) and the copyright owner(s) are credited and that the original publication in this journal is cited, in accordance with accepted academic practice. No use, distribution or reproduction is permitted which does not comply with these terms. 